\title{
Margaret McCartney: We can save billions without cutting care
}

\author{
Margaret McCartney general practitioner
}

Glasgow

The Public Accounts Committee is doing what it does well: counting the pounds and asking where the pennies are. Its reports are worth reading, as examples of cross party truth seeking.

But what of its most recent report, NHS Treatment for Overseas Patients ? $^{1}$ This concluded that the NHS and Department of Health must do "more to promote public confidence that the money due to the NHS is being recovered, and that the system is fair to taxpayers and to patients who are entitled to free care." The committee says that a target of $£ 500 \mathrm{~m}$ is to be recouped in 2017-18.

Right on cue, Jeremy Hunt has announced a crackdown. From 1 April hospitals in England will have a legal duty to charge patients who are not UK residents before any non-urgent, planned treatment.

The planet's power axis is shifting rapidly. Donald Trump is unleashing a vitriolic assault on the rights of US citizens on the basis of their birthplace. His unchecked anger and false statements litter his Twitter feed. Many protesters have cited a new wave of racist language directed at them or their friends and colleagues. We in the UK seem to have made friends with Trump while expensively trying to disengage from our European neighbours. It's worth remembering that people who voted for Brexit were lied to, infamously, with the claim that " $£ 350 \mathrm{~m}$ a week" could go to the NHS instead of the EU.

\section{Management consultants cost the NHS £630m in 2014 despite a lack of evidence that their proposals saved money or delivered safer care}

The Public Accounts Committee is right in seeking to protect NHS funds. Meanwhile, many sections of the media seize on stories of people coming to the UK to allegedly take advantage of healthcare they can't afford to pay for. J Meirion Thomas has claimed that this amounts to "billions each year."” This is wrong. The overall NHS budget was around £116bn in 2016 . $^{3}$

The $£ 500 \mathrm{~m}$ savings target equates to just 10 days of the Vote Leave campaign's claim of $£ 350 \mathrm{~m}$ a week. But we don’t know what $£ 500 \mathrm{~m}$ will cost to recoup. It will be time spent on identity checks, paperwork, a new staff administrative department, debt collectors, and a portion of debt that will be documented, forever unpaid, and written off. This is high value spending: people from other countries get the treatment they need in a crisis. What of the poor value spending in the NHS?

Management consultants cost the NHS $£ 630 \mathrm{~m}$ in $2014^{4}$ despite a distinct lack of evidence that many of their proposals saved money or delivered safer care. ${ }^{5}$ The seven day services policy has been costed by economists as requiring $£ 1.07 \mathrm{bn}-£ 1.43 \mathrm{bn}$ to implement-despite a lack of evidence showing that it will eradicate the "weekend effect." The cost of implementing the Health and Social Care Act 2012 is estimated at around $£ 1.5 \mathrm{bn}{ }^{7}$

Some ways to save money don't rely on not treating people, and for decades mechanisms to recoup money have been available. The focus on charging overseas patients shows a health secretary trying to limit embarrassing press coverage rather than trying to tackle the big problems facing the NHS.

And some other costs are worth counting. About $40 \%$ of NHS doctors qualified outside the UK. ${ }^{8}$ If the NHS treats only patients who produce a passport, what would the impact be for those doctors we need here, and their families?

Collecting fees owed to the NHS is part of a systemic and global problem, and it can be tackled better at government level. In the meantime, we should be taking better care of billions of pounds at home.

Competing interests: See www.bmj.com/about-bmj/freelancecontributors/margaret-mccartney.

Provenance and peer review: Commissioned; not externally peer reviewed.

Follow Margaret on Twitter, @mgtmccartney

Public Accounts Committee NHS treatment for overseas patients. 30 Jan 2017. https:/ www.publications.parliament.uk/pa/cm201617/cmselect/cmpubacc/771/77103.htm\# idTextAnchor004.

2 Meirion Thomas JM. Health tourism is much worse than anyone admits-and it costs us BILLIONS: Consultant's warning as MPs says NHS is being exploited by foreigners. Daily Mail 3 Feb 2017. www.dailymail.co.uk/news/article-4186478/Health-tourism-admits.html.

3 King's Fund. The NHS budget and how it has changed. 15 Jan 2016. https://www. kingsfund.org.uk/projects/nhs-in-a-nutshell/nhs-budget. 
4 Oliver D. Stop wasting taxpayers' money on management consultancy for the NHS. BMJ 2014:356:g7243. doi:10.1136/bmj.g7243 pmid:25491703.

5 Hwang MJ, Bhangu A, Webster CE, Bowley DM, Gannon MX, Karandikar SS. Unintended consequences of policy change to watchful waiting for asymptomatic inguinal hernias. Ann R Coll Surg Eng/2014;356:343-7. doi:10.1308/003588414X13946184902000. pmid: 24992416.

6 Meacock R, Doran T, Sutton M. What are the costs and benefits of providing comprehensive seven-day services for emergency hospital admissions? Health Econ 2015;356:907-12. doi:10.1002/hec.3207 pmid:26010243.
7 Appleby J. The cost of reform. King's Fund. 11 Feb 2015. https://www.kingsfund.org.uk/ blog/2015/02/cost-reform.

8 Fullfact. EU immigration and NHS staff. 11 Jul 2016. https://fullfact.org/immigration/ immigration-and-nhs-staff/.

Published by the BMJ Publishing Group Limited. For permission to use (where not already granted under a licence) please go to http://group.bmj.com/group/rights-licensing/ permissions 